\title{
New records, range extensions and descriptions for some unfamiliar Australian Lejeuneaceae (Jungermanniopsida)
}

\author{
Matt A.M. Renner \\ National Herbarium of New South Wales, Mrs Macquaries Road, Sydney, NSW 2000.
}

\begin{abstract}
Cololejeunea triapiculata is newly recorded for Australia from epiphyllous material collected on Mt Bartle Frere. Additional collections, descriptions and illustrations, are provided for Cololejeunea haskarliana and Lepidolejeunea integristipula, two other species recently reported from Australia. A further three species, Cheilolejeunea ventricosa, Lejeunea bischlerae and L. sordida, are reported new for New South Wales. Finally, the name Cololejeunea planissima replaces C. aoshimensis, as it is the correct name for Australian material previously identified as C. aoshimensis.
\end{abstract}

\section{Introduction}

Australia has a large and diverse liverwort flora, with 869 accepted species and infraspecific liverwort and hornwort taxa listed by McCarthy (2003), nearly 20\% of which belong to the Lejeuneaceae, the largest family of leafy liverwort (Schuster 1963). Knowledge of Australian Lejeuneaceae has been improved in recent years by a number of investigators including Grolle (1982) who reviewed the family in Tasmania, Thiers \& Gradstein (1989) who revised Lejeuneaceae subf. Ptychanthoideae for Australia, and Thiers (1988) who revised Cololejeunea for Australia. However, new records continue to increase the size of the Australian Lejeuneaceae flora, particularly Cololejeunea. Several Aphanolejeunea species, now all transferred to Cololejeunea (Pócs \& Bernecker 2009), were reported by Pócs \& Streimann (1999) from Queensland, Zhu \& Lai (2005) recorded two Cheilolejeunea species new for Australia, and Pócs \& Streimann (2006) reported ten new Lejeuneaceae, including three Cololejeunea species, for Australia. Here I report another Cololejeunea species new to Australia and provide additional distributional Australian records for some other species. The Australian record of C. aoshimensis is confirmed and updated, by replacement with the name C. planissima. The additional taxon reported here brings the number of Cololejeunea species known from Australia to 36 (including Aphanolejeunea). Descriptions and illustrations are here provided, as well as additional localities for some other unfamiliar Lejeuneaceae, newly recorded for Australia in recent years. 
Cheilolejeunea ventricosa (Schiffn.) X.-L.He, Acta Bot. Fenn. 163: 60. 1999.

Basionym: Pycnolejeunea ventricosa Schiffn., Consp. Hepat. Arch. Ind.: 261. 1898.

Type: Indonesia: Maluku: Moluccas Is. [Pulau Ambon], Amboina [Ambon], 1875, Naumann s.n. (FH).

Description: Zhu \& Lai (2005).

Illustration: Zhu \& Lai (2005).

Specimens examined: Australia, New South Wales, North Coast, Mt Warning National Park, Mt Warning summit track, $900 \mathrm{~m}, 28^{\circ} 24^{\prime} \mathrm{S} 153^{\circ} 16^{\prime} \mathrm{E}, 17$ June 2005, M.A.M. Renner $1430 \mathrm{c}$ \& E.A.Brown, NSW865956.

Distribution and habitats: Cheilolejeunea ventricosa is known from Mauritius, China, Malaysia, Singapore, Indonesia, Papua New Guinea, and Queensland, Australia. The first Australian record was based on a single collection made by Ilma Stone from Kennedy National Park in June 1984, and was mixed with Schiffnerolejeunea tumida var. haskarliana. Unfortunately no detailed habitat information was available. Pócs \& Streimann (2006) reported additional collections and localities for Queensland. Cheilolejeunea ventricosa is here reported new for New South Wales, from Mt Warning where it grew on bark sloughing from fallen branches hanging above the forest floor beneath a broken canopy. Presumably $C$. ventricosa had established as a branch epiphyte in the canopy of the low stature forest that grows on the flanks of Mt Warning. Cheilolejeunea ventricosa co-occurred with Drepanolejeunea sp., Frullania spp., and Mastigolejeunea calcarata.

Recognition: Cheilolejeunea ventricosa can be recognised by: 1) the strongly inflated leaf lobules which are; 2) two thirds as long as the leaf lobes with; 3 ) an evenly curved keel; and 4) the lobule arch fused with leaf lobe across 2-5 leaf cells; and 5) the suborbicular leaves that are 6) strongly convex.

Cololejeunea haskarliana (Gotts.) Benedix, Feddes Repert. 134: 57. 1953.

Basionym: Lejeuena haskarliana Lehm. et Lindenb., Novarum et Minus Cognitarum Stirpium Pugillus 8: 26. 1844.

Type: Indonesia: Java: "Habitat in Java insula, ubi in aliis Jungermaniis repentem. Legit cl. Haskarl". Type material not located.

Description: [from Australian material] forming extensive diffuse green networks of radiating shoots on leaves. Shoots green when fresh, fading to brown in herbaria, medium sized for genus, to $13 \mathrm{~mm}$ long and $0.8 \mathrm{~mm}$ wide, branching frequent but irregular, shoot system monomorphic, lateral branches similar in stature to parent branch. Stems with internal walls slightly thickened and with triangular trigones of primary wall at cell wall junctions, five cortical cells, one ventral cell row and one medulla cell roughly the same size as the larger cortical cells. Rhizoids derived from ventral cortical cell, always in groups of eight arranged in two rows of four. Dorsal leaf-free strip absent. Branching Lejeunea-type, collar a shredded ring 1 or 2 cells high continuous around branch base, persistent. Lobes obovate, 330-470 $\mu \mathrm{m}$ long and 200$290 \mu \mathrm{m}$ wide, erect when moist and dry, contiguous, stem partially obscured by lobes in dorsal view; apex rounded, flush at acroscopic base; margins spinulose due to sharply papillose cells, except for base of acroscopic margin which is entire. Cells of lobe surface sharply papillose, lobe cell surfaces unornamented. Lobules always normally developed, 
no explanate morphs seen in Australian material; one tenth the lobe area, 115-240 $\mu \mathrm{m}$ long and 76-110 $\mu \mathrm{m}$ wide, ovate carinal region inflated, pyriform, cells smooth, keel gently arched through $45-50^{\circ}$, cells smooth at base but papillose in outer half; antical margin arched, base obscured by carinal region, outer third usually visible; with two teeth, the first tooth unicellular, apex rounded, cell elongate, pointing toward shoot apex; first tooth overlapping second tooth; second tooth unicellular, cell triangular, apex acute, more or less perpendicular to first tooth, mostly obscured by first tooth in ventral view, though apex usually projects beyond side of first tooth; papilla absent from all mature lobules examined, in immature lobules affixed to the inner surface first tooth cell at its base, possibly dislodged as second tooth grows behind first tooth, as second tooth is absent from juvenile lobules. Stylus present on young lobules, filiform, 2-celled, deciduous. Medial lobule cells quadrate to rectangular, becoming progressively larger and more elongate from lobe margin to lobe base, basal cells subocellate, forming an indiscrete cluster in lobe base, cell walls straight, triangular trigones present, medial wall thickenings absent. Asexual reproduction by substellate 20 -celled gemmae; bilaterally symmetrical, pentagonal, with obtuse cells at points of pentagon, and typically three initial-cells that have conspicuously bulging cell lumens, one above each of the lateral point cells and one between the ventral point cells; produced from ventral lobe surface, occasionally in abundance. Dioicous (?). Males not seen. Gynoecia subtended by a single Radula-type innovation with rhizoid field then leaf. Female bracts in one pair, symmetrical, bracts 320-370 $\mu \mathrm{m}$ long and 150-190 $\mu \mathrm{m}$ wide at widest point, obovate, plane, margins spinulose, lobules 190-240 $\mu \mathrm{m}$ long and 150-170 $\mu \mathrm{m}$ wide, oblong, margins dentate. Perianths dorso-ventrally compressed, trapeziform in transverse section, becoming plano-convex as sporophyte grows, 420-470 $\mu \mathrm{m}$ long and 230-260 $\mu \mathrm{m}$ wide, trapeziform in transverse section, dorsal carina lacking, lateral and ventral carinae prominent, both retained as sporophyte grows and pushes outward on ventral face of perianth, upper perianth cells on all faces and all carinae sharply papillose, basal perianth cells smooth, rectangular, leptodermous; rostrum short, less than one cell tier high. Sporophytes not known in Australia.

Specimens examined: Australia, Queensland, Cook District, Wooroonooran National Park, Mt Bartle Frere, vicinity of northern summit, 15 July 2005, M.A.M. Renner 2266 \& E.A. Brown, NSW867281.

Distribution and habitats: known from Cambodia, Vietnam, Malaysia, Indonesia (Java) and New Caledonia (Tixier 1985). In Australia C. haskarliana is known from three locations in the Wet Tropics Bioregion: Mossmann Gorge, the Mt Finlayson Range and Mt Bartle Frere. On Mt Bartle Frere, C. haskarliana grew as an epiphyll on Blechnum sp. Cololejeunea haskarliana exhibits broad altitudinal tolerance in Australia, and is known to occur between 110 and 1500 m elevation.

Recognition: Cololejeunea haskarliana can be recognised by: 1) cells of lobe surface and margin armed with spinulose papillae; 2) erecto-patent leaves standing away from substrate; 3) first lobule tooth overlapping and obscuring the second lobule tooth, which 4) points sideways and is perpendicular to the first lobule tooth; 5) lobule keel with spinulose papillae at outer end; 6) pentagonal 20-celled gemmae produced from underside of leaf lobe; 7) spinulose margins of female bract lobules; 8) box-shaped perianths lacking evidence of a dorsal carina and having 9) spinulose-papillose perianth walls; 10) stems with a single medulla cell row and five cortical cell rows (Fig. 1). 
Remarks: Cololejeunea haskarliana was first reported for Australia by Pócs \& Streimann (2006) from Mossman Gorge and the Mt Finlayson Range between $110 \mathrm{~m}$ and $310 \mathrm{~m}$ altitude.

Cololejeunea triapiculata (Herzog) Tixier, Gard. Bull. Singapore 25: 344. 1971.

Basionym: Leptocolea triapiculata Herzog, Ann. Bryol. 5: 95. 1932.

Type: Asia, Indonesia, Sumatra "Fort de Kock (leg. K. v. Goebel, n.17c...)”. Type material not located.

Description: [from Australian material] forming pale green patches of radiating shoots on leaves. Shoots pale green when fresh, fading in herbaria, large for genus, to $19 \mathrm{~mm}$ long and $2 \mathrm{~mm}$ wide, branching infrequent and irregular, shoot system monomorphic, lateral branches similar in stature to parent branch. Stems with external and internal walls unthickened except for triangular trigones of primary wall at cell wall junctions, seven cortical cells, the three ventral cells smaller than others, and one medulla cell roughly the same size as the larger cortical cells. Dorsal leaf-free strip absent. Branching Lejeunea-type, collar a discontinuous ring 1 or 2 cells high, apparently deciduous, leaving branches appearing collarless. Lobes oblong, 640-900 $\mu \mathrm{m}$ long and $560-840 \mu \mathrm{m}$ wide, closely adpressed to substrate on younger shoot sectors when moist, orientation unchanged when dry, on older shoot sectors lobes disrupted and elevated by perianths, imbricate, stem obscured by lobes in dorsal view; apex broadly rounded, minutely auriculate at acroscopic base; margins irregularly crenulate due to collapsed cell walls, lobes bordered by 2 or 3 tiers of elongate, colourless cells. Cells of lobe surface not papillose or mamillose, dorsal lobe cell surfaces punctulate, ventral lobe cell surfaces smooth. Lobules always normally developed, no explanate morphs seen in Australian material; one tenth the lobe area, 250-440 $\mu \mathrm{m}$ long and 200-280 $\mu \mathrm{m}$ wide, obrhombiform with truncate apex, more or less flat, carinal region weakly inflated, keel arched evenly through $90-135^{\circ}$, smooth, without mamillose or papillose cells; antical margin straight, mostly visible though mid portions may be weakly inrolled; with three teeth, the zeroth and second teeth typically claw-like, comprised of 1 or 2 cells on a 2-celled base; first tooth unicellular atop one tier of projecting lobule cells, either 1 or 2 cells wide; lobule papilla attached to the lobule margin at the junction between the projecting lobule cell and the tooth cell, and may be partially fused with the margin of the tooth cell, imparting an anvil-like appearance to the first lobule tooth; in small lobules the zeroth lobule tooth may be absent. Medial lobule cells elongate, with sinuous cell walls. Asexual reproduction absent. Autoicous. Androecia on lateral branches that may continue vegetative growth, androecial bracts imbricate, lobules epistatic, $210-240 \mu \mathrm{m}$ long and $115-130 \mu \mathrm{m}$ wide, the antical margin strongly inrolled behind next youngest bract, each containing a single antheridium. Gynoecia subtended by a single Radula-type innovation with rhizoid field then leaf. Female bracts in one pair, symmetrical $800-920 \mu \mathrm{m}$ long and $460-740 \mu \mathrm{m}$ wide at widest point, obovate, plane, with border of 2 or 3 tiers of elongate hyaline cells, lobules $400-530 \mu \mathrm{m}$ long and 150-180 $\mu \mathrm{m}$ wide oblong, margins dentate. Perianths dorso-ventrally compressed, box-shaped at first, becoming plano-convex as sporophyte grows, 980-1060 $\mu \mathrm{m}$ long and 600-640 $\mu \mathrm{m}$ wide, trapeziform in transverse section, dorsal carina lacking, lateral carinae prominent, ventral carinae faint, lost as sporophyte grows and pushes outward on ventral face of perianth, carinae unarmed; perianth cells smooth. Rostrum short, less than one cell tier high. Sporophytes not known in Australia. 
Specimens examined: Australia, Queensland, Cook, Wooroonooran National Park, Mt Bartle Frere, 15 July 2005, M.A.M. Renner 2267 \& E.A. Brown, NSW867282; M.A.M. Renner 2268 \& E.A. Brown, NSW867283.

Distribution and habitats: known from Sri Lanka, Malaysia, Indonesia (Sumatra and Java) (Tixier 1985) and from Réunion, the Seychelles, Bhutan, Southern China, Cambodia and the Philippines (Zhu \& So 2001). New to Australia, where known from a single locality within the Wet Tropics Bioregion of north-eastern Queensland, growing in complex notophyll vine forest as an epiphyll on leaves of rainforest trees and shrubs in and around a small dry gully. Cololejeunea triapiculata co-occurred with Cololejeunea ocelloides, Cololejeunea veillonii, Colura sp., Cheilolejeunea subg. Xenolejeunea spp., Drepanolejeunea spp. Leptolejeunea sp., and Strigula sp.

Recognition: Cololejeunea triapiculata can be recognised by the combination of: 1) 2 or 3 tiers of hyaline thin-walled cells bordering leaf lobes; 2 ) punctulate ornamentation on dorsal surface of leaf lobe cells; 3 ) the obrhombiform lobules; bearing 4) three lobule teeth; with 5) first tooth unicellular atop a single tier of projecting lobule cells, either 1 or 2 cells wide; 6 ) the lobule papilla attached to the lobule margin at the junction between the projecting lobule cell and the tooth cell, sometimes partially fused with the margin of the tooth cell, imparting an anvil-like appearance to the first lobule tooth; 7) the zeroth and second lobule teeth typically claw-like, comprising 1 or 2 cells on a 2-celled base; 8 ) dorso-ventrally compressed perianths bearing four carinae, box-shaped when young, becoming plano-convex as sporophyte matures and thus obscuring the two ventral carinae; 9) the relatively large size of the plants (Fig. 2).

Remarks: Cololejeunea inflata Steph., as Cololejeunea oshimensis (Horik.) Benedix, was reported by Meagher (2003) from Mt Lewis, Queensland, but the record was not vouchered as there was "insufficient material". Cololejeunea triapiculata is similar in many respects to $C$. inflata, and the record of $C$. oshimensis could be based on a misidentification of a sporeling or other depauperate material of $C$. triapiculata. The two species share 1) a leaf lobe border of hyaline, thin-walled, cells, 2) a truncate lobule apex, 3) a claw-like second lobule tooth, and 4) a prominent first lobule tooth. Technical differences associated with the number of lobule teeth, which may be variably expressed in young specimens; the position of the hyaline papilla, which may be shed from mature lobules; and the nature of lobe cell surface ornamentation, may be overlooked — any of these factors could have contributed to confusion between these two species.

Lejeunea bischlerae B.Thiers, Cryptogamie Bryologie Lichenologie 18: 223. 1997.

Type: Australia, Queensland, Yungaburra, Gillies Road, near Mt Nomico, 8 Sept. 1985, G.A.M. Scott s.n. (holotype: MUCV6939, isotype: NY)

Description: Thiers (1997).

Illustration: Thiers (1997).

Specimens examined: Australia, New South Wales, North Coast, Border Ranges National Park, Tweed Ranges Road, unnamed lookout, 725 m, 28 $27^{\circ} \mathrm{S} 153^{\circ} 0^{\prime} \mathrm{E}, 19$ June 2005, M.A.M. Renner $1500 b$ \& E.A. Brown, NSW866036.

Distribution and habitats: known only from Australia, originally described from its above given holotype locality in Queensland and from a paratype also collected by Scott at Millaa Millaa, Zillies Falls Rd., 6 Sept. 1985 (MUCV 7068). New to New South Wales where known from two localities, one in the Border Ranges National Park, 


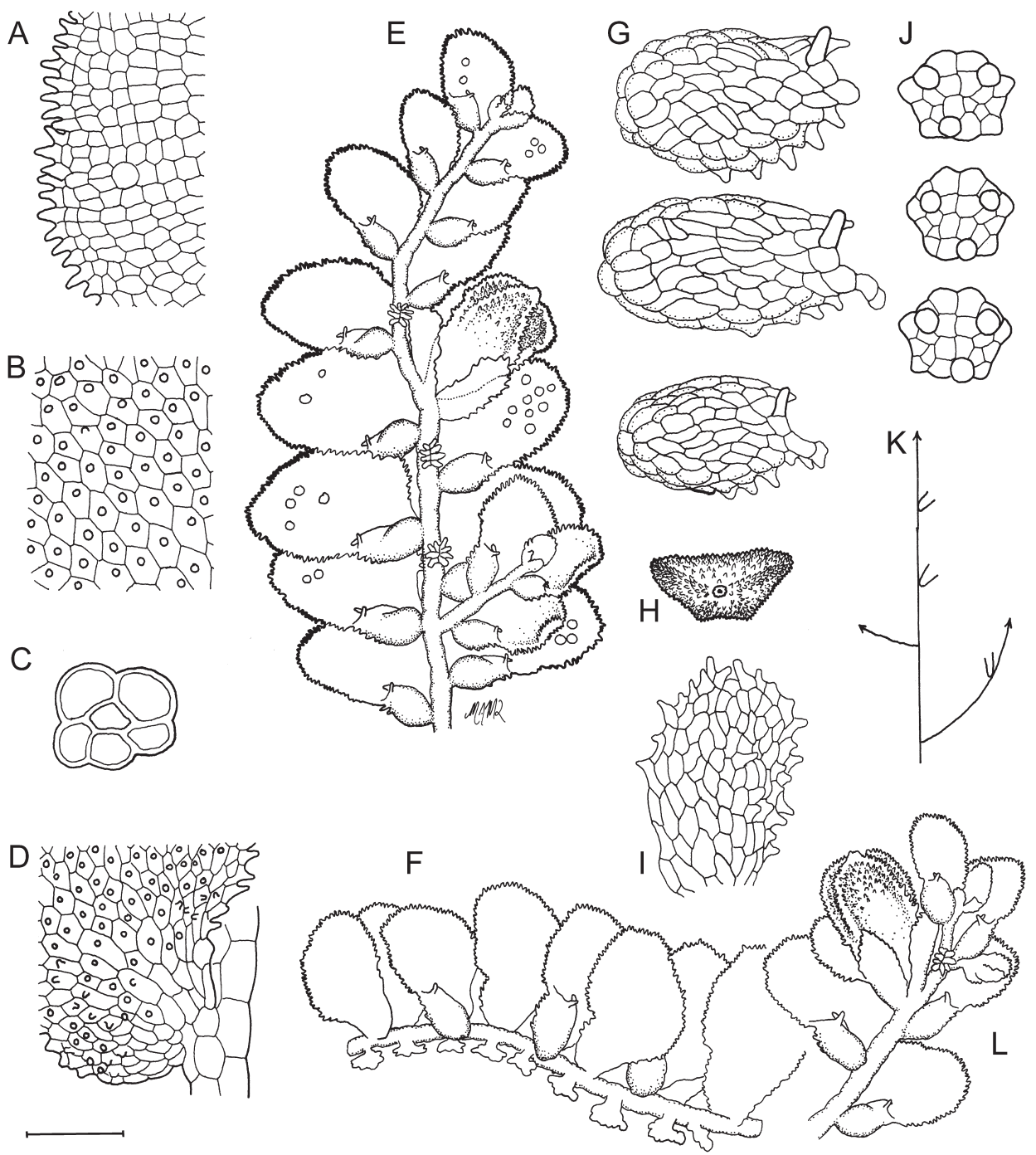

Fig. 1. Cololejeunea haskarliana A, lobe marginal cells, mammillae indicated at margin only. B, lobe medial cells. C, stem transverse section. D, acroscopic leaf lobe base. E, shoot, ventral view. F, shoot, lateral view. G, lobule. H, perianth end view. I, apex of female bract lobule. J, gemmae. K, cladogram, L, fertile shoot. All from NSW867281. Scale bar: A-D, I, J = $45 \mathrm{~mm}$; $\mathrm{E}-\mathrm{H}, \mathrm{L}=240 \mathrm{~mm} ; \mathrm{G}=30 \mathrm{~mm}$. 


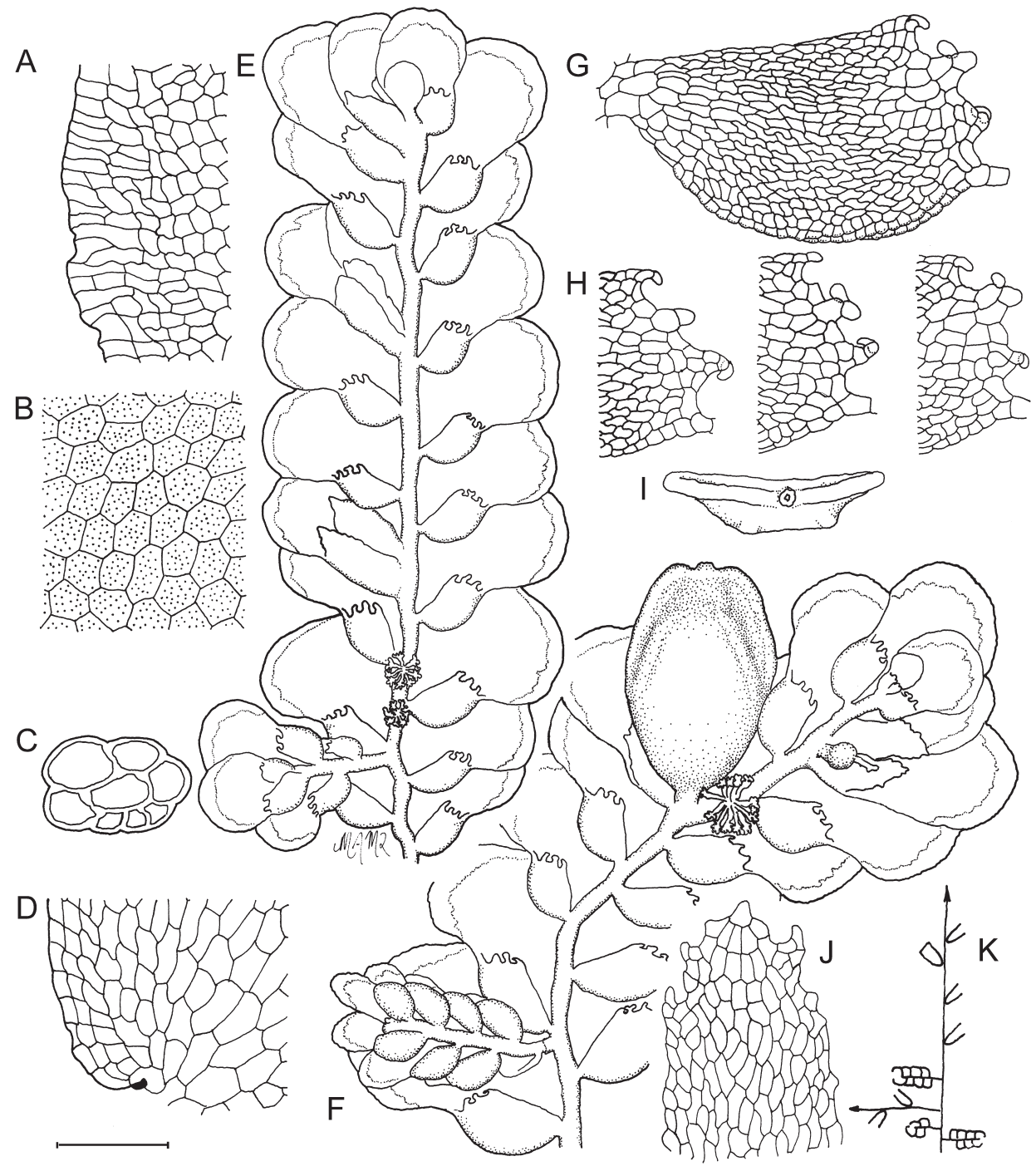

Fig. 2. Cololejeunea triapiculata A, lobe marginal cells. B, lobe medial cells. C, stem transverse section. D, acroscopic leaf lobe base. E, shoot, ventral view. F, lobule. G, lobule apices. H, perianth end view. I, autoicous shoot ventral view. J, apex of female bract lobule. K, cladogram. All from NSW867283. Scale bar: A-C, G, H, J = $50 \mathrm{~mm}$; D $=45 \mathrm{~mm}$; E, F, I = $240 \mathrm{~mm}$. 
the other within Mt Warning National Park (see L. sordida, below). In both locations L. bischlerae grew corticolous on mid-branches of subcanopy trees adjacent gaps in cloud forest. Species growing with L. bischlerae include Cheilolejeunea spp., Cololejeunea floccosa, Lejeunea sordida, Lejeunea spp. and Leptolejeunea subacuta.

Recognition: Lejeunea bischlerae can be recognised by: 1) the granular ornamentation on the dorsal and ventral lobe cell surfaces (more pronounced on dorsal surface), 2) small size, shoots c. $500 \mu \mathrm{m}$ diameter, 3) relatively large lobule, c. 0.6 lobe area, 4) small, rotund underleaves scarcely wider than the stem.

Lejeunea sordida (Nees) Mont., Ann. Sci. Nat. Bot., ser. 2, 3: 211. 1835

Basionym: Jungermannia sordida Nees, Enum. Pl. Crypt. Jav. 41. 1830.

Type: Indonesia: Java: 'in tumulis Baduorom sanctis' Lindenb. Hep. 6480 (isotype: W).

Description: Mizutani (1970).

Illustration: Mizutani (1970).

Specimens examined: Australia, New South Wales, North Coast, Mt Warning National Park, Mt Warning summit track, $900 \mathrm{~m}, 28^{\circ} 24^{\prime} \mathrm{S} 153^{\circ} 16^{\prime} \mathrm{E}, 17$ June 2005, M.A.M. Renner 1441 \& E.A. Brown, NSW865976; M.A.M. Renner $1436 a$ \& E.A. Brown, NSW865969.

Distribution and habitats: new to New South Wales, where only known from Mt Warning on the north coast. At Mt Warning Lejeunea sordida grew as a trunk epiphyte on underside of a leaning tree trunk in low forest, and as a branch epiphyte on small branches of canopy trees on a forest edge adjacent an open expanse of exposed bedrock. Lejeunea sordida co-occurred with Cheilolejeunea spp., Frullania spp., Lejeunea bischlerae, Lejeunea spp., Lopholejeunea sp., and Metzgeria spp. Overseas L. sordida is widely distributed throughout Asian-Oceanic regions.

Recognition: Lejeunea sordida can be recognised by 1) the granular ornamentation on the dorsal and ventral lobe cell surfaces (more pronounced on dorsal surface); 2) the large, broadly ovate underleaves, $5-8 \times$ the stem width; that are 2) imbricate; 3 ) bifid and 4) have subauriculate bases; 5) the strongly inflated lobule carinal region, with inrolled lobule antical margin that is obscured in ventral view; 6) the squat obpyriform lobules; 7) the distinct notch, typically $90^{\circ}$, at the keel-lobe junction; 8) the distinct knee in the lobule arch associated with this notch; 9) the keel emerging at right angles to the stem and curving through $90^{\circ}$; 10) the bright yellow-green colour when fresh; 11) gynoecia produced terminally on leading axes, subtended by a single Lejeunea-type subfloral innovation that is again fertile, causing gynoecia to appear pseudolateral.

Lepidolejeunea integristipula (Jack \& Steph.) R.M.Schust., Phytologia 45: 425. 1980.

Basionym: Pycnolejeunea integristipula Jack \& Steph. Bot. Centralbl. 60: 107. 1894.

Type: Fiji, Viti insulae, Ovalau, in monte Tana-lailai, 1864, Graeffe (holotype fide Piippo (1986): G-20388)

Description: [from Australian material] forming pale green patches of long and parallel shoots on logs, trunks and leaves, also as scattered shoots entwined within dense epiphytic bryophyte mats. Shoots green when fresh, fading to yellow-brown then brown in herbaria, medium sized for family, to $17 \mathrm{~mm}$ long and $1.2 \mathrm{~mm}$ wide, branching infrequent and irregular, shoot system monomorphic, lateral branches 
similar in stature to parent branch. Stems with seven rows of large inflated cortical cells, external walls thickened and yellow pigmented, cortical cells with bulging trigones, 10 15 rows of small medulla cells, bulging trigones at cell angles, walls yellow-pigmented. Rhizoids brown. Dorsal leaf-free strip absent, leaf insertion interlocking across the dorsal cortical cell. Branching Lejeunea-type, collar several discoid bracts, persistent. Lobes rotund-ovate, falcate, 380-680 $\mu \mathrm{m}$ long and 310-370 $\mu \mathrm{m}$ wide, spreading and weakly obliquely patent when moist, imbricate, stem obscured by lobes in dorsal view; apex rounded, lobe margins serrulate due to angular projection from each marginal cell, except at acroscopic and basiscopic base where marginal cells are smooth and margins entire; margins occassionally bearing rhizoids. Cells of lobe smooth, lobe cell surfaces unornamented, cell walls without secondary thickenings throughout except marginal cells which have triangular trigones at angles; with 15-20 ocelli scattered throughout, slightly larger otherwise weakly differentiated from surrounding cells in herbarium material (in living material visible as reflective points at $20 \times$ magnification). Lobules always normally developed, no explanate morphs seen in Australian material; one twentieth the lobe area, $80-110 \mu \mathrm{m}$ long and $100-150 \mu \mathrm{m}$ wide, ovate carinal region inflated, transversely and broadly ovate-rotund, cells smooth, keel emerging at acute angle of $45-60^{\circ}$ from stem, arched through $15-30^{\circ}$, apex well postical to stem insertion, cells smooth to bulging; antical margin incurved, obscured in ventral view; with first tooth only, unicellular, falcate and acute, pointing sideways or backward; second tooth absent; papilla pyriform to spathulate, attached to lobule margin on the base of the first tooth cell. Underleaves reniform, $270-350 \mu \mathrm{m}$ long and 360-640 $\mu \mathrm{m}$ wide 6-7x stem width, insertion arched, contiguous to imbricate, margins entire to serrulate, with ocelli scattered throughout. Asexual reproduction by caducous leaves, frequent, older shoot sectors may be entirely devoid of leaf lobes, lobes fragmenting at base, leaving basal 1 or 2 cell tiers affixed to stem at acroscopic end. Dioicous (?). Males not seen. Gynoecia terminal on leading axes, subtended by a single Radula-type innovation bearing Pycnolejeuneoid innovation sequence that continues vegetative growth and may again be fertile. Female bracts in one pair, subsymmetrical, one slightly small and with lobule apex acuminate, bract lobes obovate, 690-780 $\mu \mathrm{m}$ long and 470-550 $\mu \mathrm{m}$ wide at widest point, plane, margins serrulate, lobules 560-650 $\mu \mathrm{m}$ long and 260$310 \mu \mathrm{m}$ wide the larger oblong, the smaller ovate, margins serrulate. Bract underleaf rotund to slightly obovate, $630-690 \mu \mathrm{m}$ long and $610-680 \mu \mathrm{m}$ wide, margins serrulate. Perianths and sporophyte not known in Australia.

Specimens examined: Australia: Queensland: Cook: Daintree National Park: Myall Beach campground, 4 m, 11 July 2005, M.A.M. Renner 2056 \& E.A. Brown, NSW867276; M.A.M. Renner 2057 \& E.A. Brown, NSW867277; Dubuji broadwalk near the northern end of Myall Beach, 11 July 2005, M.A.M. Renner 2062 a \& E.A. Brown, NSW867278; M.A.M. Renner 2064 \& E.A. Brown, NSW867280.

Distribution and habitats: Lepidolejeunea integristipula is distributed throughout Asian-Oceanic regions from Borneo to Fiji (Pócs et al. 2011, this issue). Pócs \& Streimann (2006) first reported L. integristipula for Australia, from collections made in swamp forest at sea-level within Daintree National Park in the vicinity of Cape Tribulation, the same area where Dr Elizabeth Brown and I independently collected it. Lepidolejeunea integristipula inhabits a range of microsites within lowland mesophyll rainforest, including the sides of rotting logs, the trunks of rainforest trees, and the leaves of large leaved tree and shrub species, all within swamp forest. Lepidolejeunea integristipula occurred with a range of other Lejeuneaceae, including Lejeunea sp. on 
rotting logs, Lopholejeunea eulopha, Schiffneriolejeunea pulopenangensis on tree trunks, and Leptolejeunea sp. and Drepanolejeunea subg. Rhapidolejeunea sp. on leaves.

Recognition: Lepidolejeunea integristipula can be recognised by 1) the large reniform underleaves $6-7 \times$ the stem width; that are 2) entire and undivided; 3) contiguous to imbricate; 4) the lobules with sideways pointing first tooth; and 5) keel arching backward below the stem insertion, and forming an acute angle, 30-60 , with the stem; 6) the inflated carinal region and hemispherical outline of the antical half of the lobule; with 7) the antical margin obscured in ventral view; 8) the caducous leaf lobes, entire shoot sectors becoming devoid of leaves; 9) the production of marginal rhizoids from leaf lobes; 10) the presence of scattered ocelli in leaves and underleaves; 11) the crenulated lobe margin due to angular cell projections; 12) the presence of bulging trigones in stem medulla cells; 13) the vegetative branches exclusively of Lejeunea-type; and 14) the stem with cortical cells forming a distinct hyalodermis (Figs $3 \& 4$ ).

Cololejeunea planissima (Mitt.) Abeyw. Ceylon J. Sci. (Bio. Sci.) 2(1): 73. 1959.

Basionym: Lejeunea planissima Mitt. J. Proc. Linn. Soc. London 5: 117. 1861. Physocolea planissima (Mitt.) Steph., Spec. Hepat. 5: 900. 1916.

Type: Ceylon (Sri Lanka): Point Galle, Gardner 1493 (isotype: G-1956).

\section{Synonyms:}

Physocolea trianguliloba Steph., Spec. Hepat. 5: 907. 1916.

Leptocolea nakaii Horik. J. Sci. Hiroshima Univ. ser. B. div. 2, 1: 18. 1931.

Leptocolea lanciloba (Steph.) A.W.Evans var. nakaii (Horik.) S.Hatt. J. Hattori Bot. Lab. 8: 38.1952.

Leptocolea aoshimensis Horik., J. Sci. Hiroshima Univ. Ser. B, div. 2 1: 20.1931.

Cololejeunea aoshimensis (Horik.) Hattori Jol. Hattori Bot. Lab. 19: 138. 1958.

Leptocolea miyajimensis Horik., Bot. Mag. Tokyo 46: 1801932.

Description: Mizutani (1984).

Illustration: Mizutani (1984).

Specimen examined: Queensland: Wide Bay Noosa National Park, rain forest near Rangers hut, picnic point at northern point of park, Noosa Head, 14 February 1986, H. Robinson, J. Windolf $\&$ G. Batianoff 86-0114, BRI-AQ722685, as Cololejeunea near aoshimensis.

Distribution and habitats: distributed from Sri Lanka, through South-East Asia, including Vietnam and Malaysia. In Australia known from a single location in Queensland where it occurred as an isolated patch on the trunk of a rainforest tree.

Recognition: Cololejeunea planissima is similar to C. lanciloba but can be distinguished from that species by differences in the nature of the hyaline leaf border, the shape of the leaf lobe, and the shape of the leaf lobe basal cells, as summarised in the key to these 


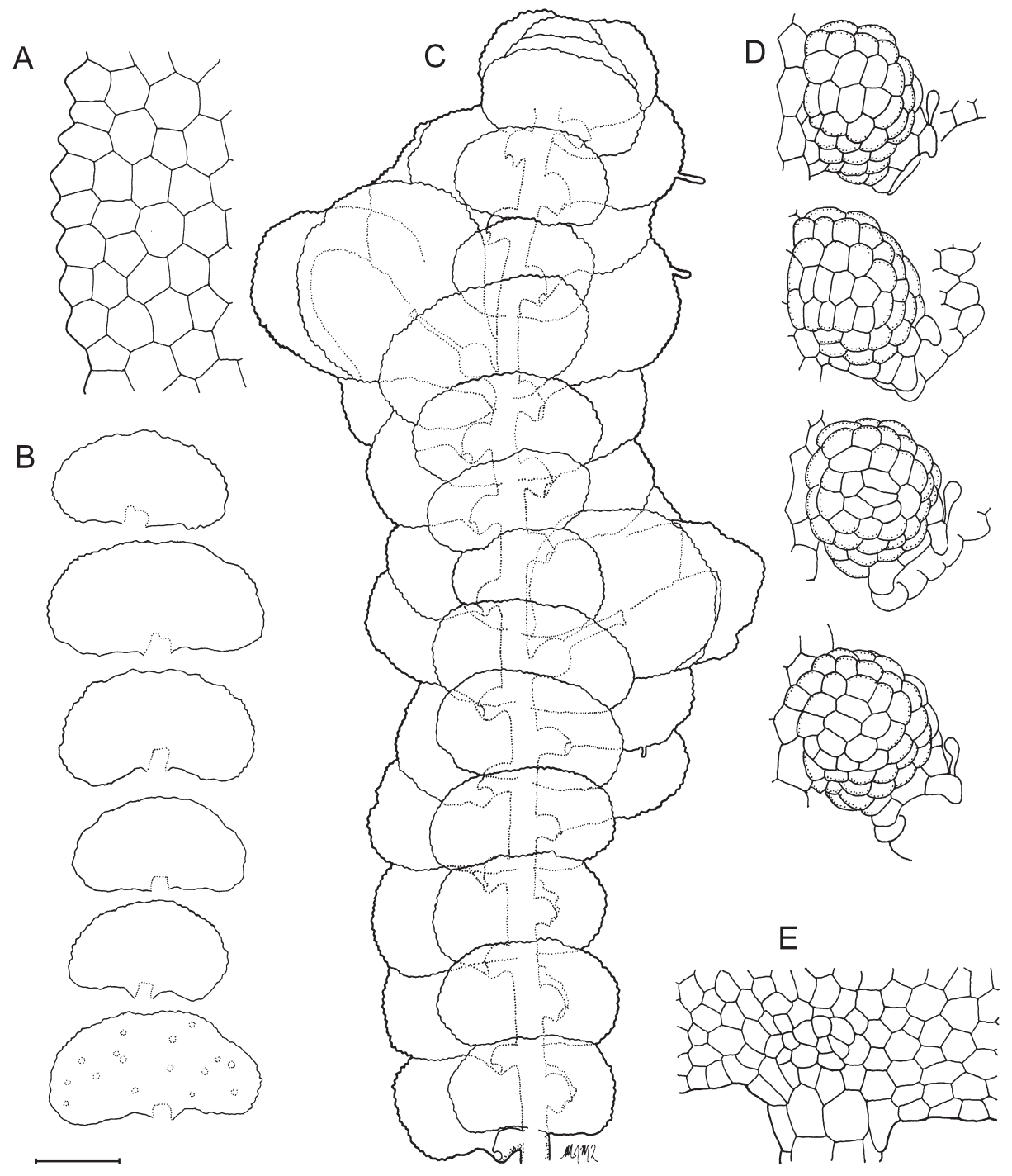

Fig. 3. Lepidolejeunea integristipula. A, lobe marginal cells. B, underleaves. C, shoot, ventral view. D, lobules. E, underleaf base. All from NSW867277. Scale bar: A $=35 \mathrm{~mm}$; B, C $=240 \mathrm{~mm}$; $\mathrm{D}, \mathrm{E}=50 \mathrm{~mm}$. 


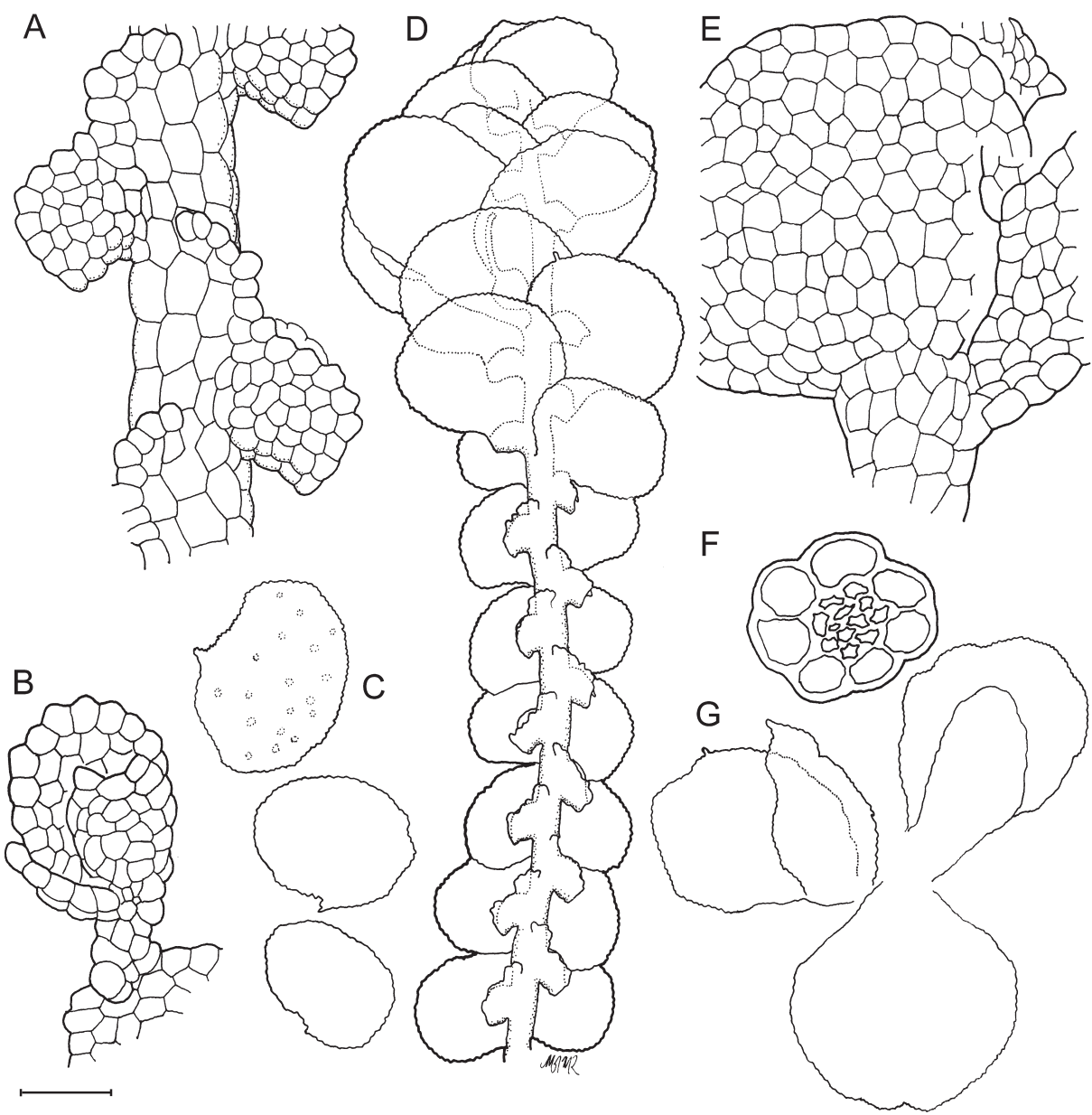

Fig. 4. Lepidolejeunea integristipula. A, stem, dorsal view. B, regenerant from lobe margin. C, caducous leaf lobes, ocelli indicated on one lobe. D, shoot, dorsal view. E, base of subfloral innovation, bract lobule at right, first branch underleaf at centre. $\mathrm{F}$, stem transverse section. G, female bract gyre, flattened. All from NSW867277. Scale bar: A-C $=60 \mathrm{~mm}$; C-E, $\mathrm{G}=240 \mathrm{~mm} ; \mathrm{F}=40 \mathrm{~mm}$. 
species presented by Mizutani (1984: 433), which I reproduce below:

1. Ventral margin of leaf-lobe bordered by hyaline cells; flat leaf-lobule usually narrowly triangular with acute apex; basal cells of dorsal side of leaf-lobe flexuous; usually on living leaves

C. lanciloba

1. Ventral margin of leaf-lobe not bordered by hyaline cells; flat leaf-lobule usually ligulate with rounded apex; basal cells of dorsal side of leaf-lobe rectangular; usually on tree-trunks C. planissima

Remarks: Cololejeunea planissima replaces C. aoshimensis for Australian material known by the latter name. Cololejeunea aoshimensis was listed as a synonym of C. planissima by Mizutani (1984) who noted that the latter was "Closely related to C. lanciloba", a species that also occurs in Australia.

\section{Acknowledgments}

I thank DERM (Department of Environment and Resource Management) for granting a permit to collect in Queensland; Elizabeth Brown (NSW) for company in the field; Anders Hagborg (F) and the ELPT (Early Land Plants Today) community for assistance with type details, references and species citations; Katherine Downs (NSW) for assistance with the NSW collections database; and two anonymous reviewers for comments on the manuscript.

\section{References}

Grolle R (1982) Ubersicht der Lejeuneaceae in Tasmanien. Wissenschaftliche Zeitschrift der Friedrich-Schiller-Universitaet Jena Naturwissenschaftliche Reihe 31: 207-227.

McCarthy P (2003) Catalogue of Australian Liverworts and Hornworts. Flora of Australia Supplementary series number 21. Australian Biological Resources Study: Canberra.

Meagher D (2003) New and interesting bryophyte records. Australasian Bryological Newsletter 48: 8-9.

Mizutani M (1970) Lejeuneaceae, subfamilies Lejeuneoideae and Cololejeuneoideae from Sabah (North Borneo). Journal of the Hattori Botanical Laboratory 33: 225-265.

Mizutani M (1984) Notes on the Lejeuneaceae. 9. Cololejeunea lanciloba and its related species in Japan. Journal of the Hattori Botanical Laboratory 57: 427-442.

Piippo, S. 1986. A monograph of the genera Lepidolejeunea and Luteolejeunea (Lejeuneaceae, Hepaticae). Acta Botanica Fennica 132: 1-69.

Pócs T \& A Bernecker (2009) Overview of Aphanolejeunea (Jungermanniopsida) after 25 years. Polish Botanical Journal 54: 1-11.

Pócs T \& H Streimann (1999) Epiphyllous liverworts from Queensland, Australia. Bryobrothera 5: $165-172$.

Pócs T \& H Streimann (2006) Contributions to the bryoflora of Australia, I. Tropical Bryology 27: 19-24.

Pócs T, Sass-Gyarmati A, Naikatini A, Tuiwawa M, Braggins J, Pócs S \& von Konrat M (2011) New liverwort (Marchantiophyta) records for the Fiji Islands. Telopea 13: 455-494.

Schuster RM (1963) An annotated synopsis of the genera and subgenera of Lejeuneaceae. Nova Hedwigia Beihefte 9: 1-203.

Thiers B (1988) The Australian species of Cololejeunea. Beiheft zur Nova Hedwigia 90: 113-146.

Thiers B (1997) Lejeunea bischlerae, a new species of Lejeunea subgenus Microlejeunea from Australia. Cryptogamie Bryologie Lichenologie 18: 223-226. 
Thiers BM \& Gradstein SR (1989) Lejeuneaceae (Hepaticae) of Australia. I. Subfamily Ptychanthoideae. Memiors of the New York Botanical Garden 52: 1-79.

Tixier P (1985) Contribution a la Connaissance des Cololejeunoideae. Bryophytorum Bibliotheca Band 27. Strauss \& Kramer: Germany.

Wilson R, Gradstein SR, Schneider H \& Hienrichs J (2007) Unravelling the phylogeny of Lejeuneaceae (Jungermaniopsida): Evidence for four main lineages. Molecular Phylogenetics and Evolution 43: 270-282.

Zhu R-L \& Lai M-J (2005) Cheilolejeunea decursiva (Sande Lac) R.M. Schust. and C. ventricosa (Schiffn) XL He (Lejeuneaceae, Hepaticae) new to Australia. Journal of the Hattori Botanical Laboratory 98: 193-203.

Zhu R-L \& So ML (2001) Epiphyllous liverworts of China. Nova Hedwigia, Beiheft 121: 1-418.

Manuscript received 12 January 2011, accepted 04 August 2011 